\title{
Preparation of complement-fixing antigen for routine use in diagnosis of Eaton pneumonia
}

\author{
ELLI JANSSON \\ From the Municipal Bacteriological Laboratory, Aurora Hospital, \\ Helsinki, Finland
}

SYNOPSIS A technique by which Eaton P.P.L.O. complement-fixing antigen, suitable for routine use, can be prepared in an ordinary bacteriological laboratory is described in detail.

Since 1944, when Eaton, Meiklejohn, and van Herick isolated from specimens of sputum from patients with primary atypical pneumonia an agent believed to be a virus, a serological method has been sought for the diagnosis of this disease. In 1957, Liu evolved an indirect fluorescent antibody technique in which frozen sections of infected chick embryo lung serve as antigen. This is understandably a very inconvenient and laborious method and quite unsuitable for routine studies. Its use has in fact been restricted to a few research laboratories. Of great importance, therefore, was the finding by Marmion and Goodburn in 1961 that under the electron microscope the Eaton agent resembled pleuropneumonia-like organisms (P.P.L.O., Mycoplasmataceae). Chanock, Hayflick, and Barile (1962a) then showed that the organism grows on Difco P.P.L.O. culture medium. They identified the colonies as Eaton agent by immunofluorescent tests with acute and convalescent phase sera from patients with Eaton pneumonia and a rabbit antiserum prepared against the Eaton agent. Chanock, James, Fox, Turner, Mufson, and Hayflick (1962b) were the first to succeed in preparing Eaton P.P.L.O. complementfixing antigen.

Even before this, the complement-fixation test for other P.P.L.O. species devised by Campbell and Turner as early as 1936 had been used by Klieneberger-Nobel (1962), Card (1959), and Lemcke (1962). Stokes (1955) and Melén and Gotthardson (1955) also studied antibodies against Mycoplasma hominis from patients with P.P.L.O. infection by the complementfixation technique.

The preparation of complement-fixing antigen from a P.P.L.O. species which grows on simpler media than the Eaton P.P.L.O., e.g., M. hominis, may sometimes be attended by difficulties. These

Received for publication 9 September 1963. are still greater with Eaton P.P.L.O. which requires special culture media. In the present work Eaton P.P.L.O. complement-fixing antigen was prepared with a technique which is a combination and modification of the methods of Klieneberger-Nobel (1962), Lemcke (1962), and Chanock et al. (1962b).

\section{MEDIA AND METHODS}

MEDIA Bacto P.P.L.O. agar and Bacto P.P.L.O. enrichment broth without crystal violet were used. These media were further enriched with glucose $1 \%$, unheated horse serum $20 \%$, yeast extract $2.5 \%$, and $20 \mu \mathrm{g}$. per $\mathrm{ml}$. of D.N.A. To avoid bacterial contamination, penicillin, 500 units $/ \mathrm{ml}$., and thallium acetate, in a final concentration of $1: 2,000$, were added. The $p \mathrm{H}$ of the medium was adjusted to $7 \cdot 8$. These media are called 'P.P.L.O. solid medium' and 'P.P.L.O. fluid medium' respectively.

The unheated horse serum was seitz filtered and stored at $-20^{\circ} \mathrm{C}$. The yeast extract was prepared from fresh baker's yeast as follows: $1 \mathrm{~kg}$. of yeast was cut up in 1 litre of water. The mixture was kept for one hour in a Koch steamer at +90 to $100^{\circ} \mathrm{C}$. and then stored for two weeks at $+4^{\circ} \mathrm{C}$. The clear solution was recovered, its $p \mathrm{H}$ adjusted to $7 \cdot 8$, and it was seitz filtered. A $25 \%$ solution was prepared and stored at $-20^{\circ} \mathrm{C}$. The nucleic acid was sodium salt of D.N.A. from calf thymus gland (British Drug Houses Ltd.). From it was prepared a $0.2 \%$ solution in distilled water, sterilized under a pressure of $10 \mathrm{lb}$. at $+115^{\circ} \mathrm{C}$. for $10 \mathrm{~min}$. and stored at $+4^{\circ} \mathrm{C}$.

Glucose and thallium acetate were added to the Bacto P.P.L.O. culture medium before sterilization. The $\stackrel{\mathbb{D}}{\circ}$ fluid culture medium was divided into batches of 7 and $\stackrel{0}{\rightarrow}$ $350 \mathrm{ml}$. and the solid medium into $14 \mathrm{ml}$. lots. They were kept in an autoclave under $15 \mathrm{lb}$. pressure at $+121^{\circ} \mathrm{C}$. for 15 minutes. The horse serum, yeast extract, D.N.A., and penicillin were added to the culture medium just before use. The solid medium was melted, enriched, and poured onto plates $5 \mathrm{~cm}$. in diameter, 6 to $7 \mathrm{ml}$. per plate.

The final medium for antigen preparation was made 
as follows: Agar base consisting of $14 \mathrm{ml}$. of Bacto P.P.L.O. agar enriched with $1 \%$ glucose and $4 \mathrm{ml}$. unheated horse serum were poured onto the bottom of a 1 litre Erlenmeyer flask. When the agar had solidified, $350 \mathrm{ml}$. of fluid medium containing glucose and thallium acetate was poured onto it. Then unheated horse serum, yeast extract, D.N.A., and penicillin were added as described.

EATON P.P.L.o. STRAIN The Eaton P.P.L.O. strain passage 61 was kindly sent me by Dr. L. Hayflick, The Wistar Institute, Philadelphia. It was subcultured at our laboratory, chiefly on P.P.L.O. solid medium, at intervals of seven to 10 days by incubating aerobically at $+37^{\circ} \mathrm{C}$. The passages were initiated by rubbing a small block of agar, measuring 1-1.5 sq. cm., over the surface of a fresh plate. The agar block was cut from an area with a microscopically heavy, almost confluent growth of typical P.P.L.O. colonies. When a confluent growth had been obtained on the plate by continuing this procedure, P.P.L.O. was inoculated further in P.P.L.O. fluid medium tubes, by cutting into very small pieces from the agar plate with a sterile knife an area of about 2 to 3 sq. $\mathrm{cm}$. and putting them in a P.P.L.O. fluid medium tube.

INOCULuM Ten ml. of the Eaton P.P.L.O. culture which had grown for seven days was inoculated without agar blocks from two or three tubes into each Erlenmeyer flask containing agar base and P.P.L.O. fluid medium. The Eaton P.P.L.O. culture used for the successful antigen preparation was the ninth passage at our laboratory.

CONTROLS From the cultures used for the inoculum, controls were made on P.P.L.O. solid medium and horse blood agar plates. On the former a very heavy growth of P.P.L.O. colonies was obtained in 10 days. The blood agar plates showed after a week infinitely small colonies hardly visible to the naked eye around which there was pronounced $\beta$ haemolysis.

CULTIVATION This was performed aerobically at $+37^{\circ} \mathrm{C}$. for 10 days. The flasks were shaken once daily. As distinct turbidity appeared in the fluid, samples were taken on blood agar plates after four and 10 days to establish possible bacterial contamination. The agar base, which had partially broken up when the flasks were shaken, was then filtered off through six layers of sterile gauze. Phenol was added to a final concentration of $0.5 \%$. A heavy sediment now formed. Incubation was continued at $+37^{\circ} \mathrm{C}$. for four days.

PREPARATION OF THE STOCK ANTIGEN FROM P.P.L.O. BROTH CULTURE The broth culture was heated in a $+56^{\circ} \mathrm{C}$. water bath for $30 \mathrm{~min}$. and thereafter was concentrated by centrifugation in an International centrifuge model PR-1 (head no. 291) at 10,000 r.p.m. $(g 8,000)$ for 30 minutes. The sediment was resuspended in sterile physiological saline in $1 / 30$ of the original volume. The resuspension was still a thick soup. It was further diluted 1:10 in sterile physiological saline. This stock antigen was stored at $+4^{\circ} \mathrm{C}$. Immediately before use it was further diluted $1: 4$.

A control antigen was prepared simultaneously in the same manner but without the Eaton P.P.L.O. inoculum.

TITRATION OF THE ANTIGEN The optimal dilution of the stock antigen was determined by parallel titrations with varying dilutions of stock antigen and known positive serum. Two units of both complement and haemolysin were used in the main test. Pooled sera with a cold agglutinin titre of $\geqq 256$ from patients with pneumonia served as 'positive serum'. The optimal dilution for the antigen obtained by this 'chessboard' titration was $1: 40$. The antigen was anti-complementary in the dilution 1:10 but no longer in the dilution of $1: 20$.

\section{DISCUSSION}

When preparing Eaton P.P.L.O. complementfixing antigen, it is desirable to use a well-enriched culture medium which contains in addition to unheated horse serum and yeast extract, glucose according to Chanock et al. (1962b) and D.N.A. according to Klieneberger-Nobel (1962). The addition of penicillin and thallium acetate is important for prevention of bacterial contamination.

In my opinion, an agar base and a heavy inoculum are two essential requirements in the preparation of Eaton P.P.L.O. complement-fixing antigen. I made several unsuccessful attempts without an agar base and with a smaller inoculum. Both Edward (1954) and Kleineberger-Nobel (1962) have established that growth of P.P.L.O. in a fluid medium improves greatly in the presence of a solid agar medium. Non-Eaton P.P.L.O. antigen is prepared from a very small inoculum, $1 \mathrm{ml}$. of an overnight broth culture. The much slower growth of Eaton P.P.L.O. is probably the reason why a larger inoculum is required.

It is possible to obtain a good Eaton antigen yield with the method described simply by centrifuging the culture broth at 10,000 r.p.m. The second centrifugation, at 40,000 r.p.m. used by Chanock et al. (1962b), can thus be omitted. Eaton antigen can therefore be prepared in an ordinary bacteriological laboratory which as a rule has no Spinco centrifuge.

During these experiments my attention was drawn to the strong $\beta$ haemolysis produced by Eaton P.P.L.O. colonies on horse blood agar plates. According to clyde (1963), the haemolysis is typical only of Eaton P.P.L.O. but in the studies of Huisjmans-Evers and Ruys (1956) M. fermentans and salivarium also regularly gave clear-cut haemolysis.

I wish to express my sincere thanks to Dr. KlienebergerNobel and Dr. Lemcke who discussed their P.P.L.O. 
methods with me and Dr. Hayflick who was kind enough to send me the Eaton P.P.L.O. strain. I was assisted by a grant from the Sigrid Jusélius Foundation. The skilled technical assistance of Miss Sirkka-Liisa Tuuri is gratefully acknowledged.

\section{REFERENCES}

Campbell, A. D., and Turner, A. W. (1936). Bull. Coun. sci. industr. Res. Aust., 97, 11.

Card, D. H. (1959). Brit. J. vener. Dis., 35, 27.

Chanock, R. M., Hayflick, L., and Barile, M. F.(1962a). Proc. nat. Acad. Sci. (Wash.), 48, 41.

—, James, W. D., Fox, H. H., Turner, H. C., Mufson, M. A., and Hayflick, L. (1962b). Proc. Soc. exp. biol. (N.Y.), 110, 884.
Clyde, W. A. Jr. (1963). Science, 139, 55. Eaton, M. D., Meiklejohn, G., and van Herick, W. (1944). J. exp. Medi
79, 649.

Edward, D. G. ff. (1954). J. gen. Microbiol., 10, 27.

Huijsmans-Evers, A. G. M., and Ruys, A. C. (1956). Antonie vLeeuwenhoek, 22, 371.

Klieneberger-Nobel, E. (1962). Pleuropneumonia-Like Organismō (PPLO) Mycoplasmataceae. Academic Press, London and New York.

Lemcke, R. (1962). Personal communication.

Liu, C. (1957). J. exp. Med., 106, 455.

Marmion, B. P., and Goodburn, G. M. (1961). Nature (Lond.), 189 sి 247.

Melén, B. J., and Gotthardson, A. (1955). Acta path. microbiol $\vec{\circ}$ scand., 37, 196.

Stokes, E. J. (1955). Lancet, 1, 276.

\section{Broadsheets prepared by the Association of Clinical Pathologists}

The following broadsheets (new series) are published by the Association of Clinical Pathologists. They may be obtainede from Dr. R. B. H. Tierney, Pathological Laboratory, Boutport Street, Barnstaple, N. Devon. The prices include postage, but airmail will be charged extra.

3 The Detection of Barbiturates in Blood, Cerebrospinal Fluid, Urine, and Stomach Contents. 1953. L. C. NICKOLLS. $1 \mathrm{~s}$.

4 The Estimation of Carbon Monoxide in Blood. 1953. D. A. STANLEY. 1s.

13 The Identification of Serotypes of Escherichia coli Associated with Infantile Gastro-enteritis. 1956. JOAN TAYLOR. 1s.

16 Preservation of Pathological Museum Specimens. 1957. L. W. PROGER. $1 \mathrm{~s}$.

17 Cultural Diagnosis of Whooping-cough. 1957. B. W. LACEY. 1s.

20 Investigation of Porphyrin/Porphyria. 1958 (reprinted 1962). C. RIMINGTON. $2 \mathrm{~s}$.

23 The Dried Disc Technique for Bacterial Sensitivity Tests. 1959. R. W. FAIRBROTHER and J. C. SHERRIS. 1s.

24 Safe Handling of Radioactive Tissues in the Laboratory and Post-mortem Room. 1959. R. C. CURRAN. 1s.

26 The Periodic Acid-Schiff Reaction. 1959. A. G. E. PEARSE. 1s.

28 Daily Fatty Acid Excretion. 1960. A. c. FRAZER. 2s.

29 The Preparation of Bone for Diagnostic Histology. 1960. D. H. Collins. 2s.

30 Control of Accuracy in Chemical Pathology. 1961. G. H. GRANT. 4s.

31 Investigation of Haemorrhagic States with Special Reference to Defects of Coagulation of the Blood. 1961. E. K. BLACKBURN. 4s.

32 Detection of Resistance to Streptomycin, P.A.S., and Isoniazid in Tubercle Bacilli. 1961. R. CRUICKSHANK and S. M. STEWART. 2 s.
33 The Laboratory Detection of Abnormal Haemoglobins. 1961. H. LEHMANN and J. A. M. AGER. 4s.

34 Titration of Antistreptolysin O. 1961. H. GOODER and R. E. O. WILliams. 2s.

35 The Estimation of Faecal 'Urobilinogen'. 1961. C. H. GRAY. $2 s$.

36 Quantitative Determination of Porphobilinogen and 3 Porphyrins in Urine and Faeces. 1961. c. RIMINGTON. 3s. 6d.

37 The Paper Electrophoresis of Serum and Urinary Proteins. 1961. G. FRANGLEN and N. H. MARTIN. 4s.

38 The Augmented Histamine Gastric Function Test 1961. M. LUBRAN. 2s.

39 Investigation of Haemolytic Anaemia. 1961. J. G. SELWYN. $2 s$.

40 Short-term Preservation of Bacterial Cultures. 1962. E. JOAN STOKES. 2s.

41 Serological Tests for Syphilis. 1962. A. E. WILKIN-N son. 6s.

42 The Determination of Glucose 6-Phosphate Dehy- $N$ drogenase in Red Cells. 1962. T. A. J. PRANKERD. W 2s.

43 Mycological Techniques. 1962. R. W. RIDDELL.O 3s. 6d.

44 The Laboratory Investigation of Catecholamine ${ }^{?}$ Secreting Tumours. 1963. M. SANDLER and C. R. J. T RUTHVEN. 2s.

45 Diagnostic Test for Hereditary Galactosaemia. 1963. v. SCHWARz. 2 s.

46 The Determination of Serum Iron and Total Irono Binding Capacity. 1963. A. JORDAN and D. A. PODMORE. $2 s$ 